\title{
A Case of Hypothalamic Adrenal Insufficiency Manifested Normal ACTH Response to Insulin-Induced Hypoglycemia
}

\author{
GoJI HASEGAWA AND EISHI ASHIHARA* \\ The First Department of Internal Medicine, Kyoto Prefectural University of Medicine, Kyoto 602-8566, Japan \\ * The Department of General Medicine, Kyoto Prefectural Rakuto Hospital, Kyoto 605-0041, Japan
}

\begin{abstract}
A low plasma ACTH response to insulin-induced hypoglycemia and an exaggerated and delayed plasma $\mathrm{ACTH}$ response to $\mathrm{CRH}$ stimulation have been considered as an indicator of hypothalamic hypopituitarism. We report a case of hypothalamic adrenal insufficiency which manifested normal ACTH response to insulin-induced hypoglycemia. This case provides important information to categorize hypothalamic adrenal insufficiency caused by abnormal regulation of $\mathrm{CRH}$ release.
\end{abstract}

Key words: ACTH, Hypothalamic adrenal insufficiency

(Endocrine Journal 47: 51-55, 2000)

\begin{abstract}
ADRENAL insufficiency results from dysfunction at one or more sites in the hypothalamic-pituitaryadrenal (HPA) axis. The distinction between pituitary and hypothalamic adrenal insufficiency is of diagnostic importance, and can usually be established using imaging studies, prolactin levels, or dynamic endocrine tests consisting of $\mathrm{CRH}$ test and insulin tolerance test (ITT) [1]. Hypoglycemic stress induced by ITT is a powerful but indirect stimulus to cortisol production via activation of hypothalamus. Therefore, low ACTH response to ITT in combination with delayed and exaggerated $\mathrm{ACTH}$ response to $\mathrm{CRH}$ suggests the presence of hypothalamic insufficiency [1-4].

Herein we report a patient with hypothalamic adrenal insufficiency who manifested normal ACTH response to ITT. This case provides us with important information to categorize hypothalamic adrenal insufficiency caused by abnormal regulation
\end{abstract}

Received: July 30, 1999

Accepted: November 5, 1999

Correspondence to: Goji HASEGAWA, M.D., Ph.D., First Department of Internal Medicine, Kyoto Prefectural University of Medicine, 465 Kajii-cho, Kawaramachi-Hirokoji, Kamikyo-ku, Kyoto 602-8566, Japan of $\mathrm{CRH}$ release.

\section{Case report}

A 65-year-old Japanese woman was admitted with persistent nausea and general malaise after recovery from common cold. She had been weary from overwork for the four months prior to the appearance of symptoms. She had never received oral administration, injection or inhalation of corticosteroids, nor did she have a history of postpartum hemorrhage, but she had experienced repeated episodes of aseptic meningitis at the age of $43,52,59$ and 60 . Her menopause occurred at age 48.

Physical examination on admission revealed that she was $147.0 \mathrm{~cm}$ height and weighed $38.0 \mathrm{~kg}$. Blood pressure was $80 / 52 \mathrm{mmHg}$ and pulse rate was $70 /$ min. Consciousness was clear. Several patches of depigmentation were noted on the skin of anterior chest, upper back and both forearms. The pubic hair was preserved, but the axillary hair was lost. No goiter was palpable. There was no abnormal finding in the chest or abdomen. Laboratory studies on admission disclosed hyponatremia $(127 \mathrm{mEq} / \mathrm{l})$ and normochromic normocytic anemia ( $\mathrm{Hb} 10.3 \mathrm{~g} / \mathrm{dl}$ ). 
Other blood chemistry findings were all within normal limits. Her symptoms, physical and laboratory findings suggested the presence of adrenal insufficiency, and the endocrinological examination revealed low serum cortisol level (less than $1.0 \mu \mathrm{g} / \mathrm{dl}$ ) and normal ACTH level $(27.2 \mathrm{pg} / \mathrm{ml})$. Adrenal insufficiency was diagnosed and she received hydrocortisone intravenously. She made a rapid recovery from the symptoms and hyponatremia after the therapy. She was well managed by oral administration of hydrocortisone at a daily dose of $10 \mathrm{mg}$ within one week after the therapy had begun.

Further endocrinological examination was performed under discontinuance of hydrocortisone (normal values are given in parentheses). Plasma ACTH level at $0600 \mathrm{~h}$ was $37.6 \mathrm{pg} / \mathrm{ml}(4.4-48.0$ $\mathrm{pg} / \mathrm{ml}$ ), with a simultaneous serum cortisol level of $3.9 \mu \mathrm{g} / \mathrm{dl} \quad(5.3-24.5 \mu \mathrm{g} / \mathrm{dl})$. Dehydroepiandrosterone sulfate level was $120 \mathrm{ng} / \mathrm{ml}(800-4600 \mathrm{ng} / \mathrm{ml})$. Urinary 17-hydroxycorticosteroid level was $2.4 \mathrm{mg}$ $/ 24 \mathrm{hr}(1.9-6.1 \mathrm{mg} / 24 \mathrm{hr})$, and Urinary free cortisol level was $25 \mu \mathrm{g} / 24 \mathrm{hr}(31-99 \mu \mathrm{g} / 24 \mathrm{hr})$. Urinary 17 -ketosteroid level was $0.2 \mathrm{mg} / 24 \mathrm{hr}(3.1-8.8 \mathrm{mg}$ $/ 24 \mathrm{hr}$ ). Circadian rhythms of both ACTH and cortisol had abnormal patterns of increase at $1600 \mathrm{~h}$. Serum aldosterone level was less than $25.0 \mathrm{pg} / \mathrm{ml}$ $(56.9-150.3 \mathrm{pg} / \mathrm{ml})$ and plasma renin activity was $0.15 \mathrm{ng} / \mathrm{ml} / \mathrm{hr}(0.5-2.0 \mathrm{ng} / \mathrm{ml} / \mathrm{hr})$. Urinary aldosterone level was $1.2 \mu \mathrm{g} / 24 \mathrm{hr}(3.0-11.4 \mu \mathrm{g} / 24 \mathrm{hr})$. Urinary adrenaline, noradrenaline and dopamine levels were $2 \mu \mathrm{g} / 24 \mathrm{hr}$ (3-15), $95 \mu \mathrm{g} / 24 \mathrm{hr}$ (26-121) and $372 \mu \mathrm{g} / 24 \mathrm{hr}$ (190-740), respectively. Serum GH level was $1.8 \mathrm{ng} / \mathrm{ml}(0.6-3.7 \mathrm{ng} / \mathrm{ml})$ and somatomedine $\mathrm{C}$ level was $40.0 \mathrm{ng} / \mathrm{ml}(121-436 \mathrm{ng} / \mathrm{ml})$. TSH level was $2.62 \mu \mathrm{IU} / \mathrm{ml} \quad(0.35-3.73 \mu \mathrm{IU} / \mathrm{ml})$, free triiodothyronin level was $1.2 \mathrm{pg} / \mathrm{ml} \quad(2.1-4.0$ $\mathrm{pg} / \mathrm{ml})$ and free thyroxine level was $0.7 \mathrm{ng} / \mathrm{dl}(0.8-$ $1.8 \mathrm{ng} / \mathrm{dl})$. Serum LH and FSH levels were 1.0 $\mathrm{mIU} / \mathrm{ml}(7.5-56.2 \mathrm{mIU} / \mathrm{ml})$ and $3.8 \mathrm{mIU} / \mathrm{ml}(9.1-$ $124.7 \mathrm{mIU} / \mathrm{ml}$ ), respectively. Estradiol level was less than $10.0 \mathrm{pg} / \mathrm{ml}$, and prolactin level was 67.3 $\mathrm{ng} / \mathrm{ml}$ (less than $15 \mathrm{ng} / \mathrm{ml}$ ).

Rapid ACTH test (Cortrosyn $0.25 \mathrm{mg}$, i.v.) revealed delayed and low response of serum cortisol. However, serum cortisol and urine 17-hydroxycorticosteroid increased on the standard ACTH test (Cortrosyn $\mathrm{Z} 1 \mathrm{mg}$, i.m. for 3 days). A single administration of human CRH (100 $\mu$ g, i.v.) induced exaggerated and delayed ACTH response (Fig. 1, top). Following insulin-induced hypoglycemia (regular insulin $0.05 \mathrm{U} / \mathrm{kg}$ ), a test examining stressmediated ACTH release, the plasma ACTH level rose to $101.0 \mathrm{pg} / \mathrm{ml}$, a normal response (Fig. 1, bottom). The cortisol response to insulin-induced hypoglycemia was slightly low and that to $\mathrm{CRH}$ stimulation revealed delayed pattern. While the GH response to insulin-induced hypoglycemia was low rising to $4.4 \mathrm{ng} / \mathrm{ml}$, the response after injection of $\mathrm{GH}$ releasing hormone (GRF $100 \mu \mathrm{g}$, i.v.) was almost normal rising to $14.0 \mathrm{ng} / \mathrm{ml}$. The response of $\mathrm{LH}$ and FSH to a single administration of LHRH (100 $\mu \mathrm{g}$, i.v.) was low. However, an augmented response of LH and FSH to LHRH was observed after five successive days of LHRH pretreatment (LHRH $100 \mu \mathrm{g} /$ day, i.m.). A peak rise in $\mathrm{LH}$ level was $10.7 \mathrm{mIU} / \mathrm{ml}$ and that in FSH level was $28.1 \mathrm{mIU} / \mathrm{ml}$. Serum TSH showed low and delayed response to TRH $(500 \mu \mathrm{g}$, i.v.) rising to a peak of $3.95 \mu \mathrm{IU} / \mathrm{ml}$ at 90 minutes after injection (basal: $2.28 \mu \mathrm{IU} / \mathrm{ml}$ ). Serum prolactin showed low response to TRH (500 $\mu$ g, i.v.) rising to $92.1 \mathrm{ng} / \mathrm{ml}$ (basal: $75.1 \mathrm{ng} / \mathrm{ml}$ ). Hypertonic saline infusion test $(5 \% \mathrm{NaCl})$ revealed no response of antidiuretic hormone (ADH) secretion to the increase of serum osmolality (Osm). ADH level and serum Osm at the beginning of the test were $0.4 \mathrm{pg} / \mathrm{ml}$ and $285 \mathrm{mOsm} / \mathrm{kg} \mathrm{H} \mathrm{H}_{2} \mathrm{O}$, respectively. A peak rise in serum Osm was $303 \mathrm{mOsm} / \mathrm{kg}$ and the ADH level at that point was $0.3 \mathrm{pg} / \mathrm{ml}$.

Antibodies against adrenal cortex and pituitary gland were not detected. Furthermore, anti-thyroglobulin autoantibody, anti-microsomal autoantibody and anti-glutamic acid decarboxylase antibody were negative.

MRI examination of the brain showed partial empty sella. No abnormal findings were detected in the hypothalamus.

The diagnosis of hypothalamic panhypopituitarism was made in this patient. She has been in good condition by the daily administration of hydrocortisone $(10 \mathrm{mg})$ alone.

\section{Discussion}

Elevated serum prolactin level and increases in pituitary hormone release after direct or successive stimulation of pituitary gland with releasing hormones are consistent with hypothalamic damage as 
CRH test ; CRH $100 \mu \mathrm{g}$, i.v.

ACTH

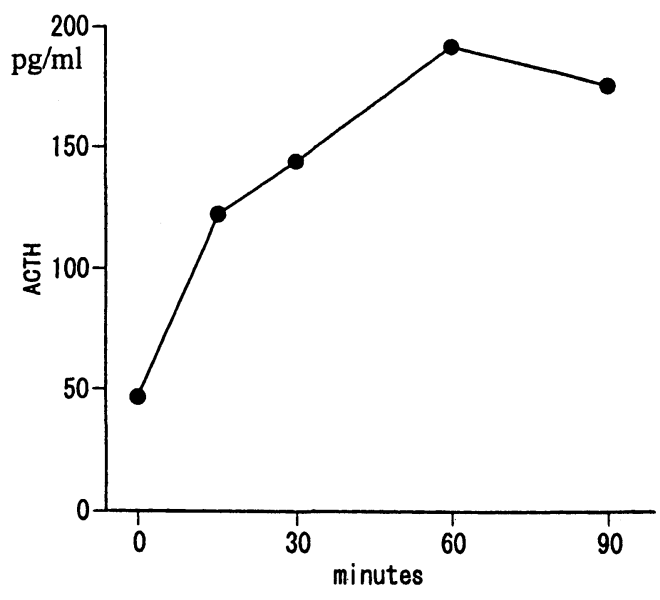

Cortisol

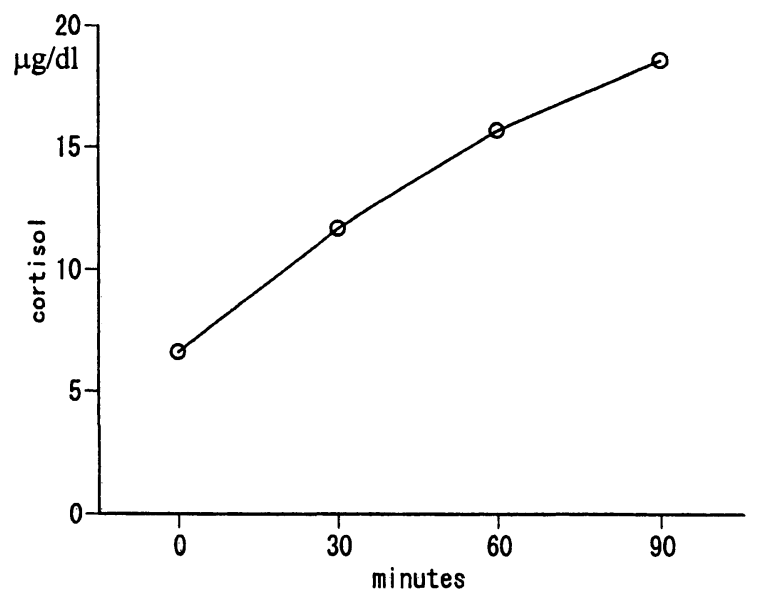

Insulin tolerance test : insulin, $0.05 \mathrm{U} / \mathrm{ml}$ i.v.

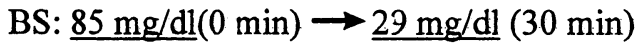

$\mathrm{ACTH}$

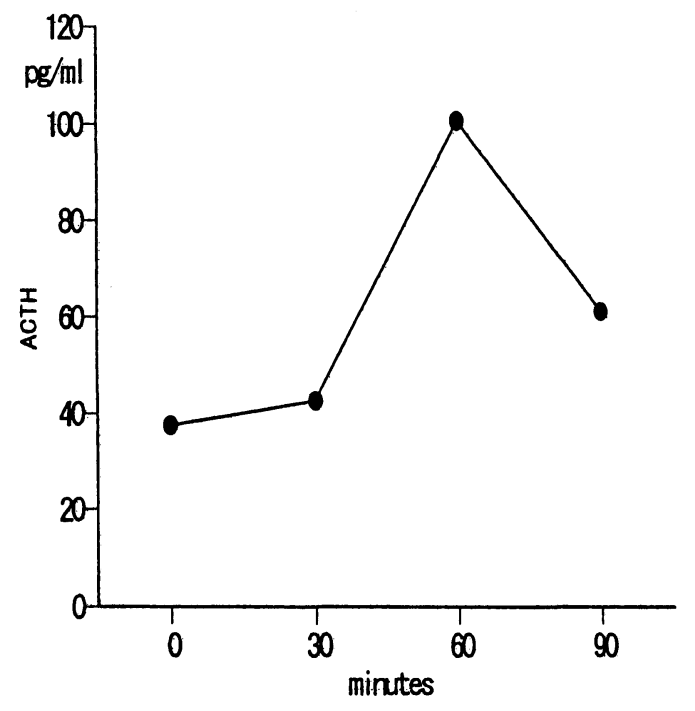

Cortisol

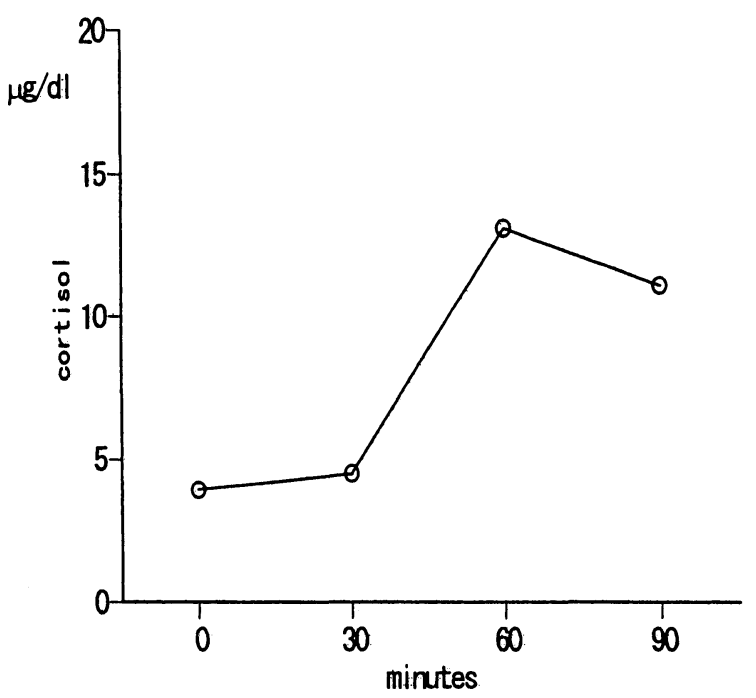

Fig. 1. Response of plasma ACTH and serum cortisol to CRH stimulation (top) and insulin-induced hypoglycemia (bottom).

a cause of hypopituitarism. In the present case, the symptoms of adrenal insufficiency induced by stress led to a diagnosis of hypothalamic pan- hypopituitarism. The abnormal circadian rhythm of ACTH may also indicate the adrenal insufficiency of hypothalamic origin. 
Low plasma ACTH response to insulin-induced hypoglycemia and exaggerated and delayed plasma ACTH response to CRH stimulation have been considered as an indicator of hypothalamic hypopituitarism [4]. However, in this case, the ACTH response to insulin-induced hypoglycemia was normal. This retention of stress-induced ACTH release would imply that the reserve of ACTH release regulator (CRH and other neurotransmitters) in hypothalamus was normal. Therefore, together with no appreciable anatomical abnormalities in hypothalamus on the MRI examination, we conjectured that some functional abnormalities (neuroendocrine abnormalities) in the hypothalamus may be the cause of adrenal insufficiency in this case.

The HPA axis manifests prominent circadian rhythmicity as well as episodic or pulsatile modes of hormone release [5]. The intermittency of secretory activity has been considered to help prevent downregulation (desensitization) of the target cells by releasing factor or trophic agent $[6,7]$. This helps to account for the pathogenesis of adrenal insufficiency in the present case. Namely, in this patient, although basal mode of $\mathrm{CRH}$ release was preserved, we speculated that intermittent burstlike CRH secretion from the hypothalamus were diminished. The subsequent loss of pulsatile ACTH release of long duration would then lead to the desensitization of adrenocortical cells, presenting secondary adrenal insufficiency $[8,9]$. A stress mechanism of ACTH release could not possibly work to release the sufficient cortisol for the increased requirements.
Although we cannot definitively account for the etiology of hypothalmic disorder seen in this patient, it is possible that, together with the presence of the partial empty sella, her repeated episodes of aseptic meningitis might have affected the hypothalamus, disturbing the neuroendocrine regulation of pituitary hormones. It should be noted that viral infections can also alter neurotransmitter and/or neuroendocrine regulation [10]. Repeated viral infections in this patient might have altered a variety of inhibitory or excitatory neurochemical systems known to modulate hypothalamic CRH release.

An etiologic classification of hypothalamic adrenal insufficiency could be subdivided according to at least two abnormalities, CRH deficiency (decreased CRH reserve) and functional disturbance of $\mathrm{CRH}$ release. CRH deficiency has been well documented to be the result of destruction of hypothalamic tissue such as tumors, inflammation, or post-radiation. Primary hypothalamic $\mathrm{CRH}$ deficiency is another rare cause $[4,11]$, but as of yet we have only limited information on the functional disturbance of CRH release. The mild central adrenal insufficiency observed in patients with chronic fatigue syndrome may be classified as a functional disturbance of $\mathrm{CRH}$ release [12]. Neurobiological regulation of CRH-ACTH release has not been elucidated, and the clinical significance of diminished pulsatile ACTH release represents an area for future investigation. The present case thus provides important information to categorize hypothalamic adrenal insufficiency caused by abnormal regulation of $\mathrm{CRH}$ release.

\section{References}

1. Grinspoon SK, Biller BMK (1994) CR 62 Laboratory assessment of adrenal insufficiency. J Clin Endocrinol Metab 79: 923-931.

2. Tsukada $T$, Nakai $Y$, Koh $T$, Tsuji S, Inada $\mathbf{M}$, Nishikawa M, Shinoda H, Kawai I, Takezawa N, Imura H (1984) Plasma adrenocorticotropin and cortisol responses to ovine corticotropin-releasing factor in patients with adrenocortical insufficiency due to hypothalamic and pituitary disorders. J Clin Endocrinol Metab 58: 758-760.

3. Schulte HM, Chrousos GP, Avgerinos P, Oldfield EH, Gold PW, Cutler Jr GB, Loriaux DL (1984) The corticotropin-releasing hormone stimulation test: A possible aid in the evaluation of patients with adrenal insufficiency. J Clin Endocrinol Metab 58: 1064-1067.

4. Nishihara E, Kimura H, Ishimaru T, Kiriyama T, Yokoyama N, Yamashita S, Nagataki S (1997) A case of adrenal insufficiency due to acquired hypothalamic CRH deficiency. Endocr $J$ 44: 121-126.

5. Veldhuis JD, Iranmanesh A, Johnson ML, Lizarralde G (1990) Twenty-four-hour rhythms in plasma concentrations of adenohypophyseal hormones are generated by distinct amplitude and/or frequency modulation of underlying pituitary secretory bursts. $J$ Clin Endocrinol Metab 71: 1616-1623.

6. Rivier C, Vale W (1983) Influence of the frequency of ovinecorticotropin releasing factor administration on adrenocorticotropin and corticosterone secretion in 
the rat. Endocrinology 113: 1422-1426.

7. Veldhuis JD, Iranmanesh A, Lizarralde G, Johnson ML (1989) Amplitude modulation of a burstlike mode of cortisol secretion subserves the circadian glucocorticoid rhythm. Am J Physiol 257: E6-E14.

8. Veldhuis JD, Iranmanesh A, Johnson ML, Lizarralde G (1990) Amplitude, but not frequency, modulation of adrenocorticotropin secretory bursts gives rise to the nyctohemeral rhythm of the corticotropic axis in man. J Clin Endocrinol Metab 71: 452-463.

9. Gudmundsson A, Carnes M (1997) Pulsatile adrenocorticotropic hormone: an overview. Biol Psychiatry 41: 342-365.

10. Oldstone MB, Sinha YN, Blount P, Tishon A, Rodriguez M, von Wedel R, Lampert PW (1982)
Virus-induced alterations in homeostasis: alteration in differentiated functions of infected cells in vivo. Science 218: 1125-1127.

11. Velardo A, Pantaleoni M, Zizzo G, Del Rio G, Coletta F, Carani C, Marrama P (1992) Isolated adreno-corticotropic hormone deficiency secondary to hypothalamic deficit of corticotropin releasing hormone. J Endocrinol Invest 15: 53-57.

12. Demitrack MA, Dale JK, Sraus SE, Laue L, Listwak SJ, Kruesi MJP, Chrousos GP, Gold PW (1991) Evidence for impaired activation of the hypothalamic-pituitary-adrenal axis in patients with chronic fatigue syndrome. J Clin Endocrinol Metab 73: 12241234. 